\title{
Sygdommens rum
}

Tidsskrift for Forskning i Sygdom og Samfund

Nr. 18, 2013 


\title{
Tidsskrift for Forskning i Sygdom og Samfund
}

\author{
Nr. 18: Sygdommens rum
}

(c) 2013 forfatterne og udgiverne.

Redaktion:

Mette Bech Risør (ansv.), Forskningsenheden for Almen Praksis, Universitetet $i$ Tromsø

Torsten Risør, Det Sundhedsvidenskabelige Fakultet, Universitetet $i$ Tromsø

Gitte Wind, Institut for Kultur og Samfund - Antropologi, Aarhus Universitet

Ann Dorrit Guassora, Forskningsenheden for Almen Praksis, Københavns Universitet

Susanne Reventlow, Forskningsenheden for Almen Praksis, Københavns Universitet

Rikke Sand Andersen, Forskningsenheden for Almen Praksis, Aarhus Universitet

Claus Bossen, Institut for Medie- og Informationsvidenskab, Aarhus Universitet

Helle Ploug Hansen, Helbred, Menneske og Samfund, Syddansk Universitet

Peer review: Foretages af et tværvidenskabeligt panel bestående af bl.a. læger, antropologer, filosoffer, historikere, psykologer, politologer og sociologer.

Proof: Stine Haslund Jønsson

Layout og prepress: Stine Haslund Jønsson

Tryk: Werk Offset, Højbjerg.

Udgiver:

Foreningen Medicinsk Antropologisk Forum,

Afd. for Antropologi og Etnografi, Aarhus Universitet, Moesgård, 8270 Højbjerg.

Bestilling, abonnement, henvendelser og hjemmeside:

Tidsskrift for Forskning i Sygdom og Samfund.

Afd. for Antropologi og Etnografi, Aarhus Universitet, Moesgård, 8270 Højbjerg

Tirsdag kl. 10-13, tlf. 87162063,

Email: sygdomogsamfund@hum.au.dk

Hjemmeside og artikler online:

ojs.statsbiblioteket.dk/index.php/sygdomogsamfund/index

ISSN (tryk): 1604-3405

ISSN (online): 1904-7975

Tidsskriftet er udgivet med støtte fra Forskningsrådet for Kultur og Kommunikation.

Formål:

Tidsskrift for Forskning i Sygdom og Samfund er et tværfagligt tidsskrift, der tager udgangspunkt i medicinsk antropologi. Tidsskriftet har til formål at fremme og udvikle den forskning, der ligger i grænsefeltet mellem sundhedsvidenskab og humaniora/samfundsvidenskab. Tidsskriftets målsætning er at fungere som et forum, hvor disse fag kan mødes og inspirere hinanden - epistemologisk, metodisk og teoretisk - i forskellige forskningssammenhænge. Tidsskriftet formidler den debat og teoretiske udvikling, der foregår i de voksende faglige samarbejds- og forskningsinitiativer, der udspringer af dette grænsefelt. Tidsskriftet henvender sig til alle med interesse for forskning i sygdom og samfund og i særlig grad til sundhedsmedarbejdere i forsknings- og undervisningssammenhæng med forbindelse til tværfaglige miljøer.

Aims and scopes

The Journal for Research in Sickness and Society is an interdisciplinary journal which has a theoretical background in medical anthropology. The aim and purpose of the journal is to promote and develop research in the borderland between the health sciences and the humanities/the social sciences. The goal of the journal is to function as a forum in which these disciplines may meet and inspire each otherepistemologically, methodologically and theoretically. The journal conveys the debate and theoretical development which takes place in the growing collaboration and research initiatives emerging from this borderland. The journal addresses all with an interest in research in sickness and society and especially health professionals working with education and/or research in interdisciplinary institutions. 


\section{Indhold}

Torsten Risør

Introduktion 5-11

Regner Birkelund

Det æstetiske indtryks betydning for sundhed, sygdom og velvære 13-20

Tenna Doktor Olsen Tvedebrink, Anna Marie Fisker \& Poul Henning Kirkegaard

Sygdommens spiserum: Har arkitekturen en overset eller glemt betydning her? 21-38

Rikke Nygaard, Mia Brandhøj, Camilla Berg Christensen \& Bent Egberg Mikkelsen

Måltidets Rum - rum for sundhedsfremme? 39-65

Hanne Bess Boelsbjerg

Det hellige rum: Sjælesorgssamtaler på hospitalet 67-86

Iben Emilie Christensen \& Sofie Ilsvard

Sygdom og selvopfattelse på tværs af rum 87-111

Birgitte Schepelern Johansen E Katrine Schepelern Johansen

At tæmme nydelsen - en analyse af den rumlige indretning af en dansk heroinklinik 113-134

Anne Kathrine Frandsen

Environmental qualities and patient well-being in hospital settings 135-158

Abstracts in English 159-163

Forfatterliste $165-167$

Skrivevejledning $\quad 168-170$

Beskrivelse af nr. 19171 


\section{Environmental qualities and patient well-being in hospital settings}

\section{Anne Kathrine Frandsen}

Statens Byggeforskningsinstitut, Aalborg Universitet akf@sbi.dk

Frandsen, A. K. (2013). De fysiske rammer på hospitaler og deres indvirkning på patienters velbefindende og helbredsforløb. Tidsskrift for forskning $i$ Sygdom og samfund, nr. 18, 135-158.

Within the last decades the impacts of the physical environments of hospitals on healing and health-care outcomes have been subject to ample research. The amount of documentation linking the design of physical environments to patient and staff outcomes is increasing. A Danish research project undertaken by Architecture and Design and the Danish Building Research Institute (Aalborg University) set out in 2008 to review research on the impact of the environmental qualities of health-care facilities on patients and staff. The objective of the review team was to develop a tool that would allow an overview of this research, needed by construction clients and decision-makers in Denmark responsible for large investments in future hospitals and healthcare environments in the decade to come.

The present paper offers an overview of the findings of the review team. Its point of departure is the categorisation developed during the study, which facilitated the sorting and communication of the findings. In this categorisation, research findings are grouped according to their focus on specific spatial qualities - such as light and acoustics - and not according to the different diagnoses, which may be linked to such spatial qualities, like stress and depression. In other words, the application of this categorisation foregrounds the importance and the convenience of looking at spatial qualities of the physical environment, when addressing issues related to patient or staff wellbeing. 


\section{Background}

Within the last decades an interest in the impact of the physical environments of hospitals on healing and health-care outcomes has developed, and research findings linking the design of physical environments with patient and staff outcomes are multiple.

One of the important reasons for this interest is the increased general knowledge about stress, indicating that stress - especially long term stress - weakens the response of our immune system, as well as impacting the body's own ability to heal (Glaser, \& Kiecolt-Glaser, 2005; Khansari, Murgo \& Faith, 1990). As serious illness - along with the break of personal routines inherent in hospitalisation - can be most stressful, knowledge of how patients' stress can be reduced and their well-being increased in hospital settings are important for hospital managements. Within the last two decades research findings have suggested that the physical environments of hospitals play a significant role when it comes to patients' stress, well-being and safety. In 2008 around 600 studies on hospital design, linking the qualities of the physical environment with patients' and staff's stress, well-being and general outcomes, were identified in a paper by Roger Ulrich and his team (Ulrich, Kellert, Heerwagen \& Mador, 2008).

In order to expand the base of evidence and widen the areas of study, the Center for Health Design in California, US, launched the Pebble Project in 2000, a joint research effort between the Center for Health Design and various healthcare providers. The objective of the Pebble Project is to engage healthcare providers who are building new healthcare facilities or renovating existing facilities in a process, where design decisions are based on the best available documentation from research on healthcare facilities. Another initiative promoting the application of the results from this field of research is Jane Malkin's book 'A Visual Reference for Evidence Based Design' (Malkin, 2007). It presents and discusses hospital facilities, where insights gained from research on physical environments and healthcare outcomes have been applied.

In a European context the research linking the design of healthcare facilities with well-being, reduced stress and the general health-care outcome has received interest in many places, and both in Great Britain, Norway, and the Netherlands research projects to compile, review and present the research findings in the field have been executed (Lawson \& Phiri, 2003; Hammerstrøm \& Bjørndal, 2007; Van der Berg, 2005). Likewise, educational initiatives have emerged among others at Chalmers in Sweden and the Berlage Institute in the Netherlands. 
In Denmark the interest for the impact of health care environments on patients and staff was initiated by the book 'Sansernes hospital' (Heslet \& Dirckinck Homfeldt, 2007). The book describes the negative effects of stress on our capability to heal, along with the stress reducing effects of light, art, and music. The book advocates for a new paradigm of hospital building - 'the hospital of the senses' as opposed to the paradigm of the modernistic hospital - 'the senseless healing machine'.

A majority of the mentioned reviews are structured either with a point of departure in the physical, psychological or economic impact of different environmental qualities on patients or staff, or in spatial solutions.

In the paper by Roger Ulrich (Ulrich, Kellert, Heerwagen \& Mador, 2008) three groups of evidence are identified, with a focus on the impact of the environment. The headings of these groups are 1) Improving patient safety through environmental measures; 2) Improving other patient outcomes through environmental measures; 3) Improving staff outcomes through environmental measures. The sub-headings refer to impacts on the subject such as pain, sleep disturbances etc. Jane Malkin has organised the material in her book 'A Visual Reference for Evidence Based Design' both in accordance with the structuring in the articles by Roger Ulrich as well as the functional entities of a hospital - the patients' passage through treatment, spaces for the staff, patient units, diagnostic areas etc.

The Norwegian review (Hammerstrøm \& Bjørndal, 2007) defines 9 categories, based on the 65 studies they present: Interior - Spatial solutions - Nature (plants, animals and sunlight) - Prevention of falls and wandering - Lighting - Noise reduction - Multisensory stimulation - Distraction (stimulation of hearing and seeing) - Miscellaneous. Two of these categories are defined as in the above mentioned papers (Prevention of falls and wandering, Distraction) with a point of departure in the impact on patients or staff. The other 7 are either based on spatial solutions (interior, spatial solution, nature) or on types of sensory stimuli (lighting, noise reduction, and multisensory stimulation).

In ASPECT (A Staff and Patient Environment Calibration Tool) by Lawson and Phiri (Lawson, 2010) categories are mixed as in the Norwegian study. The categories are: Privacy, company and dignity - Views - Nature and outdoors - Comfort and control (heat, light and sound) - Legibility of place - Interior appearance - Facilities and staff.

Only the review Health Impacts of Healing Environments (van der Berg, 2005) and the Danish book 'Hospital of the Senses' (Heslet \& Dirkinck-Holmfeld, 2007) operate with categories based on the sensory stimulation. In van der Berg's review 
the two main categories are Health benefits of nature (subdivided into Views of nature, Gardens, Indoor plants) and Health benefits of natural elements (subdivided into Daylight, Fresh air, Quiet). In Heslet and Dirkinck-Holmfeld's book two groups of sensory stimuli are included; noise/music and light/visual art. The reviews focusing on the sensory stimulation included only controlled or randomized and controlled studies.

In 2008 Architecture and Design and the Danish Building Research Institute set out to review research studying the impact of spatial or environmental qualities of hospital settings on patients and staffs. The objective was to illuminate whether environmental qualities of hospital settings have in themselves a healing potential. The review was aimed at decision-makers, building clients and architects involved in the renewal of healthcare facilities in Denmark in the decade to come.

The aim of the review was threefold:

Firstly, the aim was to pin point spatial qualities that different studies suggest have an impact on healthcare outcomes, highlighting the spatial qualities with impact (e.g. daylight, sounds, accommodation of social interaction) rather than the impacts (e.g. stress, pain). This in order to give the reader of the review overview of what spatial qualities it could be important to be aware of in briefing and design processes. In that respect the review differed from several of the above mentioned reviews.

Secondly, the aim was to not only looking at sensory stimulation but also at functional qualities such as accommodation of social interaction. In that respect it differed from other reviews focusing on spatial qualities/sensorial stimulation.

Thirdly, the review employed a broader inclusion strategy compared to other reviews focusing on sensorial stimulation regarding inclusion criteria of the study design, including studies looking at measurable impacts of physical environments, as well as at the exposed persons' experiences of space and spatial qualities.

\section{Method}

The study was conducted as a literature review. The objective was to study and communicate findings from studies on the impact of qualities of physical environments in hospital settings on well-being, stress and the general health-care outcome. Only studies focusing on design of spatial outline, layout or design of a hospital - in detail or on a bigger scale - were included.

The inclusion criteria were: 
Population:

Intervention/investigation:

Endpoints:

Study design:
Patients, staff or relatives at hospitals or rehabili tation centers.

Related to architecture or design (layout, day light, noise/sound, colour etc.).

Effect on health and healing (stress, intake of pain-relieving medicine, admission time etc.) and experiences of well-being.

Ranging from randomised controlled trials to context bound evaluations.

The review included only papers in Scandinavian and English, and only primary sources.

The reviewed literature comes from very different fields of research such as medicine, environmental psychology, psychology, anthropology and architecture. Thus, research methods in the various studies differ significantly. As the aim of the review was to illuminate the impact of the environmental qualities of hospital settings on patients and staff, including both measurable and experienced impacts, the criteria regarding study design were inclusive. Both randomized controlled studies and more context bound studies such as post occupancy evaluations were included. The quality of the studies was not assessed. A meta-analysis of the impact of the environmental stimuli was, accordingly, neither possible nor relevant, as the included studies differ with regard to study design, the account of environmental stimuli, and how effects are measured or accounted for.

In June and August 2008 a search was conducted in the following databases: forskningsdatabase.dk; bibliotek.dk; libris.se; ask.bibsys.no; amazon.com + amazon.uk.com; youtube.com. The search criteria were: free text, journal papers, all languages, year after 1998.

The search words used were 'healing architecture', 'patient + environment', 'senses + healing', 'hospital + (hygiene, ward, light, relatives, staff, sleep, acoustics, noise, pain, stress, gardens, food, appetite, layout, security)'.

The search team went through the bibliographies in the following references: Hammerstrøm, K.; Bjørndal, A. (2007) Arkitektur og design for livskvalitet og helse. En kartlegging av foreliggende forskning, no. 20, Kunnskapssenteret, Norge

Heslet L. \& Dirckinck Homfeldt K. (2007) Sansernes hospital, Arkitektens Forlag; København, Denmark

Ulrich, R.S; Quan, X.; Zimring, C.; Joseph, A.; Choudhary, R. (2004) The Role of the Physical Environment in the Hospital of the 21st Century: A Once-in-a-Lifetime Opportunity. The Center for Health Design 
Ulrich, R.S., Kellert, S. R., Heerwagen, J. H., \& Mador, M. (2008) A review of the research literature on evidence-based healthcare design. HERD, 1(3), 61.

Van den Berg, , A.E. (2005) Health Impacts of Healing Environments, Foundation 200 years

University Hospital Groningen, Nederland

A search was conducted on the websites: Center for health design.org; Sykehusplan.no.

The search led to 988 references. A review of abstracts reduced the number of relevant papers to 192 papers, which met the criteria defined above. After a review of the full-text papers, 67 references were excluded and the final review included 125 references. (Due to a stricter adherence to inclusion criteria, in the present paper the number of included studies are reduced compared to the original study).

Flowchart of literature search:

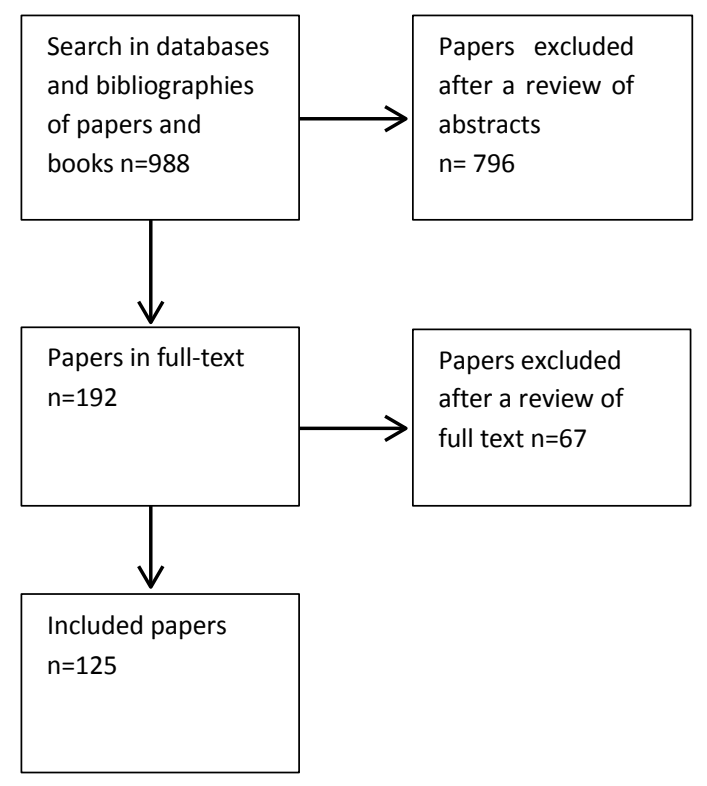

140 Tidsskrift for Forskning i Sygdom og Samfund, nr. 18, 135-158 


\section{Classification of the research findings}

The reviewed research and scientific documentation range from medical studies measuring physical responses to specific environmental stimuli to qualitative studies based on interviews about subjects' experience of the environment. A majority of the studies look only at one single environmental quality or factor, such as sound levels and their impact on sleep quality, or daylight intensity and its impact on self- registered stress or the intake of analgesics. A minor part of the studies look at two or more environmental qualities at the same time.

The objective of the review was to give architects and building clients in briefing and design processes an overview of qualities in the physical environment identified as important for the well-being of patients and staff. Therefore, the team categorised the findings emphasising the environmental qualities which a person is exposed to in hospital settings.

Architectural theoretical research based on a phenomenological tradition stresses that the experience of architecture is a multisensory experience. All senses are engaged in the experiencing of architecture, even if not all senses are addressed with intent through the design. Eiler Rassmussen describes how different senses engage in architecture, including seeing, hearing, touching as well as whole-body experiences of mass, scale and movement (Eiler Rasmussen, 1997). The architectural theoretician Juhani Pallasma develops this inclusion of the whole-body sense, basing his concepts on the psychologist James J. Gibson and his categorisation of senses in five sensory systems: The visual, the auditory, the taste-smell, the basic orienting and the haptic system. Furthermore, Pallasma stresses the multisensorial character of perception (Pallasma, 2005). Through multi-sensory perception we encounter and interact with our surroundings and their inherent social contexts.

Based on this understanding of the multisensory experience of architecture and Gibson's five sensory systems, a categorisation of findings was developed during the review. This categorisation, presented below, enables a distinction between various physical factors, which findings suggested had an impact on the wellbeing and outcome of patients and staff. The categorisation divided the findings in three themes; findings that relate sensorial stimulation of the body to wellbeing, stress reduction and healing processes of patients and staff; findings that relate the need for social relations to wellbeing, stress reduction and healing processes of patients and staff; and findings that relate security to wellbeing, stress reduction and healing processes of patients and staff. 
The studies were distributed among the following subthemes:

The impacts which stimulate the bodily senses were distributed among the subthems:

\begin{tabular}{|l|l|l|}
\hline \multicolumn{3}{|l|}{ The impacts which stimulate the bodily senses were distributed among the subthemes: } \\
\hline \multirow{3}{*}{ visual factors } & Light & $n=26$ \\
\cline { 2 - 3 } & colour and visual art & $n=1$ \\
\cline { 2 - 3 } & views to the outdoor & $n=8$ \\
\hline auditory factors & sound/noise & $n=21$ \\
\hline olfactory and taste factors & smell & $n=4$ \\
\hline basic orientation factors & movement and orientation & $n=0$ \\
\hline haptic senses & touch & $n=14$ \\
\hline The impacts of accommodating relational needs were distributed among the subthemes: \\
\hline personal space & $n=11$ \\
\hline social space & $n=5$ \\
\hline exterior space & $n=19$ \\
\hline The impacts of functionality regarding safety were distributed among the subthemes: \\
\hline hygiene & $n=15$ \\
\hline errors and injuries & \multicolumn{2}{|l|}{} \\
\hline
\end{tabular}

Some of the studies relate to two subthemes; the acoustic climate, for instance, plays an important role for the possibility of self-regulation, as well as for establishing a sense of privacy and atmosphere that encourage intimate talk - all important elements in the experience of personal space. Such studies are included under both relevant subthemes.

The presentation of the findings in this paper follows the categorisation described above, including only the sensorial stimulation and relational functionality.

\section{Findings on the impact of sensorial stimulation}

In the reviewed literature findings related to many, but not all, the bodily senses were found. The impact of the visual sense was well documented - especially light and views to the outside - whereas only a few studies on colour and visual art met the criteria for inclusion in the review. Only a few studies on smell and orientation/movement were found, whereas no studies on the impact of touch were found.

\section{Light}




\section{Satisfaction rate}

Several satisfaction surveys, post occupancy evaluations and studies of hospitals before and after alteration based on surveys or interviews indicated that access to daylight is important for everyone that spends their time at a hospital, whether as a patient, a relative or a member of staff. When asked what is important for their personal well-being and job satisfaction, access to daylight and to windows are the properties of the physical environment mentioned by a majority (Lawson \& Phiri, 2003; Leather et al., 2003; Macnaughton et al., 2005; Mroczek, Mikitarian, Vieria \& Rotrius, 2005; Shepley, 2002, Alimoglu\& Donmez, 2005). In several studies staff and patients express dislike of spaces with no windows and no access to daylight, and staff express worry for their own state of health when they work in windowless rooms (Macnaughton et al., 2005; Symon, Paul, Butchart \& Carr, 2007). That the preference for daylight depends on the given situation is indicated in a study where a majority of the women preferred privacy to light when giving birth (Symon, Paul, Butchart \& Carr, 2007). In many of these studies there is no distinction between the window as a source of light versus a visual access to the surroundings. In one study of the preferences of patients and staff on a ward for physical rehabilitation, rooms with high placed windows or windows looking at a wall scored just as low as windowless rooms (Verderber, 1986).

\section{Circadian rhythm and sleep}

Daylight together with darkness at night is crucial for maintaining our circadian rhythm. In the beginning of the 1990s light sensitive non-visualising cells in the eye (photosensitive ganglion cells) were discovered, and the stimulation of these play a major role in the synchronization of our circadian rhythm (Roenneberg \& Foster, Lack \& Wright, 2007).

Two studies, one based on registrations of the elderly's exposure to light during the day and their sleep at night, and an intervention study at a hospital ward registering exposure to light and effects on sleep rhythm, indicate a relation between the measure of time, which elderly spent in daylight or in light with high intensity during the day and the quality of their sleep at night (Wallace-Guy et al., 2002; Wakamura \& Tokura, 2001). Two intervention studies conclude that exposure to light with high intensity during the day has a positive impact on the activity and rest ration of elderly with dementia. When exposed to light with high intensity during the day the patients' level of activity at night was reduced along with their fragmented behaviour (Lovell, Ancoli-Israel \& Gevirtz, 1995; Van Someren, Kessler, Mirmiran \& Swaab, 1997). A study of the impact of exposure to light at night con- 
cludes that exposure to light over 50 lux at night has a negative impact on sleep quality (Vinzio et al, 2003).

The same pattern can be observed in children. When the lighting level differs significantly between day and night, with low levels of light at night, the sleep quality of both hospitalised children and premature babies improves, with longer periods of sleep and deeper sleep with fewer movements (Cureton-Lane \& Fontaine, 1997; Slevin et al., 2000). Seemingly, this difference between day and night not only increases the difference between premature babies' levels of activity at day or night. Studies indicate that their general level of activity increases; they put on more weight, develop quicker and are discharged earlier compared to those, who spend all their time in even semi-dark light (Altimier et al., 2005; Rivkees, Mayes, Jacobs \& Gross, 2004). Two retrospective studies that compare patients' ability to orientate themselves at intensive care units, with and without daylight, indicate that daylight has a positive impact on the patients' ability to orientate themselves (Wilson, 1972; Keep et al., 1980).

\section{Depression}

Light with high intensity has been a recognised treatment of winter depression for some time (Lewy et al, 1998; Terman et al. 2001; Benedetti et al., 2003). Now findings suggest that daylight with high intensity, especially morning light, also has a positive impact on other types of depression. Two retrospective studies based on hospital records found that patients with severe depression and bipolar depression lying on day-lit sunny wards had significantly shorter hospitalisations compared to patients with the same diagnosis lying on darker wards facing north or with neighbouring buildings shading (Beauchemin \& Hays, 1996; Benedetti et al., 2001).

\section{Admission time and mortality}

Another retrospective study based on hospital records suggests that daylight and sunny rooms are also beneficial for patients with no psychiatric diagnose. On a cardiac intensive unit the patients on sunny wards facing south had fewer complications and were discharged significantly earlier when compared to those lying on the darker wards. The sunny daylight had a remarkable impact on the admission time for women. Within this group the average admission time differed from an average of 3,3 days of admission on the darker wards to an average of 2,3 days on the sunny wards. Additionally, the mortality was lower among the patients on the sunny wards (Beauchemin \& Hays, 1998). 


\section{Pain and stress}

A prospective study of patients who have undergone a spinal surgery concludes that daylight with high intensity and sun also seems to have a positive impact on the experience of pain and stress. Patients on sunny wards facing west was exposed to $46 \%$ more light than patients with the same diagnosis on the same department lying on darker wards facing east. The first group lying on the light wards used $22 \%$ less analgesic medicine and rated their own level of stress significantly lower when discharged compared to the patients on the darker wards (Walch et al., 2005).

\section{Views to the outside}

As mentioned above, both patients and staff generally prefer spaces with windows that allow a bearing of the exterior surroundings and the course of the day, and regard it is as one of the most important spatial qualities for their well-being (Symon, Paul, Butchart \& Carr, 2007; Lawson \& Phiri, 2003; Verderber, 1986; Mroczek, Mikitarian, Vieria \& Rotrius, 2005). In surveys among the residents on three long-term care facilities views to gardens and vegetation were preferred, while people and their activity, nature scenery, the weather, animals and the sky came in second (Kearney \& Winterbottom, 2005).

\section{Distraction, pain and stress}

Being able to view green surroundings seems to be a distraction that can reduce the experience of pain and increase the threshold of pain. That is the conclusion in two studies, where subjects were viewing either a video or a picture of nature scenery while they were exposed to pain; the subjects' self-reported experience of pain was lower among those who had watched the nature scenery compared with that of control groups (Tse, 2002; Diette et al., 2003). In a retrospective study based on hospital charts of patients who had undergone a gallbladder surgery, the patients lying on wards with a view to trees and vegetation used significantly less strong analgesics, had fewer notes in the journals about anxiety and excited behavior and were discharged faster compared with the patients on the same department lying on wards with a view to a brick wall (Ulrich, 1984). A controlled study measuring the blood pressure and pulse of blood donors who were viewing either a video with nature scenery, city scenery or nothing, indicate that the nature scenery had a calming effect compared to the city scenery, while there was no difference between those viewing the nature scenery and those not exposed to any particular view (Ulrich et al., 2003). 


\section{Visual art and colour}

In the search, not many studies on the impact of art and colour were found, which met the defined criteria for inclusion in the review. Omitting the studies on videos of nature scenery referred to above (under the subheading 'Distraction, pain and stress'), only one was left: In a controlled study in a children's department children's behavior in white walled rooms was compared to their behavior in a room with tea rose coloured walls, mural paintings of dolphins, fishes and crabs and plum coloured carpet. The study suggests that the wall colours in combination with mural paintings had a calming effect on aggressive children and adolescents (Glod et al., 1994).

\section{Sound and noise}

The research included in the review concerning the acoustic environment on hospitals and its impact on patients, relatives and staff deals with the general sound level and the impact of noise on sleep quality, concentration and stress, among other measures.

Several studies recording the sound level in intensive care areas indicate that generally the sound level in these areas is too high, either due to technical equipment and alarms or the communication and activities of the staff (Busch-Vishniac et al., 2005; Falk \& Woods, 1973; Hilton, 1985; Meyer et al., 1994). Sound levels where nearly the same day and night. A comparison between three hospitals, a larger one with multi-bed wards and two smaller with single bed wards, indicates that the more patients in a room, the higher the sound level due to more sounds from individual patients and more visits by staff and relatives (Hilton, 1985; Couper et al., 1994).

\section{Sleep}

High sound levels have a negative impact on patients' sleep leading to disruptions and general reduction of the sleep quality. This is concluded in several studies based either on recordings of sound levels in relation to sleep patterns or on interviews with patients about their perception of the contribution of environmental factors to sleep disturbances (Freedmann et al., 2001; Cureton-Lane \& Fontaine, 1997; Freedmann, Kotzer \& Schwab, 1999; Topf, Bookman, Arand, 1996; Yinnon et al., 1992). An experimental study that recorded how noises in two different acoustic settings affected the test subjects' sleep showed that the same noise in a situation with reduced reverberation time reduced the frequency of sleep disruptions (Berg, 2001). Results from a study recording premature infants' response to noise 
reduction with earmuffs showed a significant increase in the infants' oxygenation of the blood and more sleep in a normal quiet state when they were wearing earmuffs (Zahr \& de Traversay, 1995). As sleep is essential in all healing processes, reductions in sleep quality result in negative physiological consequences for the patients.

\section{Physiological and experienced stress}

High sound levels seem to have a negative impact on patients' experience of anxiety. A survey among patients on respectively multi-bed wards and single-bed wards monitoring their experience of noise, sleep, privacy, isolation, friendship, anxiety and depression indicates a close connection between noise and the experience of anxiety and nervousness (Pattison \& Robertson, 1996). In a controlled study the physiological condition of premature babies in a situation with reduced sound levels (earmuffs) was compared to a normal situation (no earmuffs). The premature babies' physiological condition improved positively when the sound levels were reduced (heart rate, blood pressure and oxygenation of the blood) (Slevin et al., 2000).

Furthermore, sound levels seem to have an impact on the work environment and stress level of staff. This is indicated by an intervention study, which reduced the reverberation time in patient rooms, staff rooms and work stations in an intensive coronary care unit. With the reduction of reverberation time staff experienced increased job satisfaction, improved speech comprehension as well as a positive improvement of the work environment with fewer conflicts and less stress (Blomkvist et al., 2005). The patients perceived this improvement of the work environment as a positive change in the staffs' mood and attitude (Hagermann et al., 2005). However, a controlled study of the impact of noise or music on surgeons' stress and ability to concentrate indicates that noise or music did not disturb their performance (Moorthy et al., 2004). A controlled study of persons monitoring anaesthesia reaches the same conclusion, though the subjects experienced more stress and were less certain about their monitoring (Sanderson et al., 2005).

\section{Privacy}

Involuntarily overhearing other peoples' conversation and knowing that others are able to overhear your own conversations seems to have a negative impact on patients' experience of privacy. Lack of acoustical privacy may inspire low patient-staff confidentiality and may result in the patient withholding information 
relevant for the diagnosis or treatment (Barlas, Sama, Ward \& Lesser, 2001; Karro, Dent \& Farish, 2003; Olsen \& Sabin, 2003).

\section{Smell}

Only a single study of the impact of hospital smell and air was found when excluding hygienic aspects. The study suggests that essential oils smelling of oranges can have a calming and stress reducing impact (Lehrner et al., 2000).

\section{Orientation}

Likewise, the team did not find many studies on orientation and way-finding in hospitals. A study on a 604 bed hospital shows that patients and visitors having problems finding their way around the hospital take up a considerable amount of the staff's time, equaling the time of two full-time employees (Zimring, 1990). A few studies indicate that problems with way-finding are not solved with signage alone. The complexity of the layout and spatial reference points are of importance as well; the more complex the layout and the fewer spatial reference points, the more difficult to find the way (O'Neill, 1991a; O'Neill 1991b). The results of a study comparing the way-finding success of two groups with or without the aid of a plan, suggests that the plan was no help. The group with the plan used $15 \%$ more time in reaching the destination (Wright et al., 1993).

\section{Relational functions}

In the reviewed literature findings were made which relate all three subthemes defined under 'Relational functions' (personal space, social space and exterior space) to patient well-being and stress and improved outcomes for both patients and staff.

\section{Personal space}

The subtheme 'personal space' includes research that deals with the level of privacy of the individual patient, relative or member of staff.

\section{Satisfaction}

The reviewed literature documented that individuals' possibility for experiencing privacy and control of their own situation is important for their experiences of well-being. This does not necessarily mean that patients need single rooms, or that the experience of privacy is only achieved with single rooms (NHS estates, 
2005). Surveys with un-hospitalised persons and hospitalised persons on a maternity ward do, however, suggest that a majority would prefer single rooms (NHS estates, 2005; Symon, Paul, Butchart \& Carr, 2007). Two intervention studies indicate that a clear indication and acoustical shielding of the area 'belonging' to a bed along with the possibility of controlling light and temperature in itself increases the experience of privacy (Altimier et al., 2005; Harris et al., 2006). Likewise, in an interview study on a maternity ward patients mention a place to keep one's things as an important element in establishing a feeling of privacy (Symon, Paul, Butchart \& Carr, 2007).

\section{Relatives participation}

Support from patients' social network plays an important role when it comes to reducing the anxiety of going through a severe heart surgery. This is suggested in two studies based on questionnaires answered by patients and relatives (Tarkka et al., 2003 Koivula et al., 2002).

Privacy levels have an impact on how much relatives participate in the care of patients and on the degree of intimacy in the care. Surveys among relatives to old patients on geriatric units and relatives to residents on a long-term care facility indicate that the private space around the patient influences the degree of relatives' participation in the care (Laitinen \& Isola, 1996; Sallström, 1987). A survey among members of staff indicates that they assess single rooms as best suited to accommodate intimacy between patients and relatives (Chaudhury et al., 2004). In an intervention study on a neonatal care unit and in two comparative studies of several neonatal intensive care units more intimate relations between parents and children were achieved by means of either more shielded space around beds on a multi-bed ward or by single rooms. Parents spent more time on the ward, were more involved in the care of their babies and were considerably more inclined to hold their babies (Harris et al., 2006; Altimier et al., 2005; Prodromidis et al., 1995).

\section{Examination}

Privacy plays an important role in relation to staff's examination and treatment of patients. Several interview studies on emergency departments conclude that confidentiality is less likely if privacy is not secured, in some cases leading to situations where patients withhold important information (Barlas, Sama, Ward \& Lesser, 2001; Karro, Dent \& Farish, 2005; Olsen \& Sabin, 2003). Interviews and observations indicate that patients experience more privacy and observe fewer privacy breaches when examination rooms are separated with walls instead of 
curtains, establishing not only visual shielding but also an acoustical shielding (Barlas, Sama, Ward \& Lesser, 2001; Dent \& Farish, 2005; Olsen \& Sabin, 2003; Mlinek \& Pierce, 1997).

\section{Social space}

The subtheme 'social space' included findings that deal with patients' or relatives' need for social interaction and how the functional layout of physical environments can contribute to the fulfillment of social needs.

\section{Interaction between patients}

Talking to others who find themselves in the same situation as one-self can have a positive impact on patients and relatives. A study based on surveys with patients lying on multi-bed wards or single rooms undergoing a heart surgery, as well as on their records, indicates that patients had better emotional relations to fellow patients with the same diagnosis as their own. On wards where patients shared the same diagnosis patients were less anxious before the surgery, walked more after surgery and recovered quicker compared to patients in single rooms and on multi-bed wards where patients had different diagnoses (Kulik, Mahler \& Moore, 1996). A survey and interview study among new parents on a maternity ward found that although new parents wanted privacy, they did find the possibility for interaction with fellow new parents very important (Symon, Paul, Butchart \& Carr, 2007).

Likewise, patients' appetite is not only linked to the taste of food and the individual medical condition, but is also influenced by social interaction. This is indicated in a study conducted at a children's cancer department based on interviews, surveys and observations. Making a social event out of meals by moving the intake of meals out of the wards and corridors of the department and into a common staffed kitchen and letting children have the food they wanted, increased children's intake of food from $50 \%$ to $70 \%$ of their need (Holm, 2003; Smidt, Holm \& Fleischer, 1996).The study indicates an intricate relation between functional needs, relational interaction, and sensorial stimulation.

Several other controlled intervention studies indicate that the layout and interior decorations have an impact on the interaction between patients. When seating arrangements were altered with groups of chairs around smaller tables and atmospheres made less institutional, increased conversation between patients was observed in both psychiatric and somatic departments (Holahan \& Saegert, 1973; Holahan, 1972; Sommer \& Ross, 1958; Olsen, 1984). 


\section{Interaction between patients and staff}

The interaction between patient and staff is important in care and treatment. The presence of staff physically or visually, along with social support from staff, reduces patient anxiety and fear. This is indicated in a study based on a survey among patients about to undergo a bypass surgery (Koivula et al., 2002). A predesign and post occupancy analysis on a neonatal intensive care unit based on observations, interviews and surveys indicates that a visually and physically open spatial layout seems to help to make patients and relatives consider the staff accessible and increase the actual interaction between staff and patients or relatives (Shepley, 2002). A comparative study based on questionnaires among patients and relatives of two departments respectively with rectangular and circular layout, found that the circular layout was preferred. The qualities of the circular layout mentioned by patients and relatives were the visual contact to the staff, a sense of security, and the distraction from watching staff activities (Sturdavant, 1960).

\section{Green exterior spaces}

Outdoor areas with vegetation or actual gardens are experienced by all users of hospitals - patients, staff and relatives - as important oases that help reduce stress and facilitate both social interaction with others and privacy. This is concluded in several studies based on interviews, surveys and observations (Marcus \& Barnes, 1995; Marcus \& Barnes, 1999; Whitehouse et al., 2001). The qualities which users find attractive and uplifting are basically identical in all the studies; trees, shrubs and flowers are the elements that are primarily mentioned, along with elements that involve other sensorial stimulations, such as scents, no noise, birds, sun and shadow (Heath \& Gifford, 2001; Kearney \& Winterbottom, 2005, Marcus \& Barnes, 1999; Rodiek, 2005; Whitehouse et al., 2001; Marcus \& Barnes, 1995).

\section{Conclusions}

Rigid conclusions as to whether or not the physical environment on hospitals has a healing potential in itself, so to speak, are not possible on the basis of the review referred to in the present paper, given - among other things - that the study design involves no assessment of the quality of the reviewed studies, and no account of effect size or size of population in the reviewed studies.

It is shown in the present paper, however, that there is ample research in the field, both controlled randomized studies and qualitative studies on experiences of environment. This research includes studies on the physical environments of 
hospitals as places that stimulate people's senses (positively or negatively) and as places that do or do not accommodate people's functional or relational needs. The studies indicate that sensorial stimulation from spatial qualities such as daylight, views to the outside, acoustics and sounds, along with the spatial accommodation of the needs for privacy and social interaction, can influence the well-being, stress levels, and general outcome of patients, relatives, and staff.

Some findings may be classified directly as positive outcomes of the impact of the physical surroundings: e.g. reduced mortality, shortened admission time and a reduced intake of sedatives. Others may only be called indirect positive outcomes (e.g. an increased intimacy between parents and hospitalised children, better sleep among patients and reduced experiences of stress and anxiety), relying on research that link reduced stress or better sleep to better direct outcomes, such as reduced mortality or shorter hospital stays.

Best illuminated in the reviewed literature are the impacts of day-light with a high intensity on pain, stress, and depression, the impact of good acoustics on private conversations and sleep quality, and the impact of views and access to green exterior spaces on pain and stress. In order to establish a robustly founded insight in the role and impact of the physical environments of hospitals much more research is needed, however; through repeated studies on the spatial qualities and impacts which have already been studied, and through new studies on the impact of spatial qualities not touched upon here.

In categorising the findings of different studies into themes and subthemes of spatial qualities, the referred review indicates which spatial qualities have already been investigated and which have seemingly not. The review team did not find studies on certain types of sensorial stimulation, e.g. haptic sense, and only very few on whole-body orientation and stimulation of smell. This cannot be said to imply that these senses do not have an impact on well-being and stress levels, but merely shows that such studies did not turn up in the search conducted by the review team, or have not yet been subject to research.

The referred studies on sensorial stimuli or accommodation of relational needs look only at impacts on separate groups of patients, grouped on the basis of department or diagnosis. There are no comparative studies on the impacts of certain stimuli on different groups of patients, or on whether the documented impacts of different sensorial stimuli on a specific group of patients apply to other groups of patients. What role does e.g. high intensity day-light play within different patient groups? What role does it play in out-patient areas or waiting areas? What are the relational needs (regarding privacy and social interaction) of staff and relatives? 
What needs do patients have in waiting areas or out-patient areas? Answers to these and more questions would contribute to the consolidation of the referred field of research and its application in planning and design processes.

Though it is not possible on the basis of the referred review to conclude that the physical environment of hospital settings has a separate healing potential, the many and diverse studies referred to here, open up windows for regarding hospitals in new ways. Above all, they raise the question, whether it would not be fruitful to regard patients holistically as 'whole' persons, whose health, healing and recovery is closely linked to the stimulation of their senses, thoughts, and emotions.

\section{Referencer}

\section{Databases}

Alimoglu, M.K.\& Donmez, L., (2005) Daylight exposure and the other predictors of burnoutamong nurses in a university Hospital. International Journal of Nursing Studies, 42(5), 549.

Altimier L.M. , Eichel, M., Warner, B., Tedeschi, L., \& Brown, B (2005) Developmental care: Changing the NICU physically and behaviorally to promote patient outcomes and contain costs. Neonatal Intensive Care, 18, 4, 12

Barlas, D., Sama, A. E., Ward, M. F., \& Lesser, M. L. (2001). Comparison of the auditory and visual privacy of emergency department treatment areas with curtains versus those with solid walls. Annals of Emergency Medicine, 38(2), 135.

Beauchemain K. M, \& Hays P., (1996) Sunny hospital rooms expedite recovery from severe and refractory depressions. Journal of Affective Disorders, 40(1-2), 49

Beauchemin K. M., \& Hays P., (1998) Dying in the dark: Sunshine, gender and outcomes in myocardial infarction. Journal of the Royal Society of Medicine, 91, 352,

Benedetti F., Colombo, C., Barbini, B., Campori, E., \& Smeraldi, E. 2001) Morning sunlight reduces length of hospitalization in bipolar depression. Journal of Affective Disorders, 62(3), 221

Benedetti, F., Colombo, C., Pontiggia, A., Bernasconi, A., Florita, M., \& Smeraldi, E. (2003 Jun)Morning light treatment hastens the antidepressant effect of citalopram: A placebo-controlled trial. Journal of Clinical Psychiatry, 64(6), 648.

Berg, S. (2001) Impact of reduced reverberation time on sound-induced arousals during sleep. Sleep, 24(3), 289. Blomkvist, V., Eriksen, C.A., Theorell, T. Ulrich, R.S., \&Rasmanis, G. (2005) Acoustics and psychosocial environment in intensive coronary care, Occupational and Environmental Medicine, 62 (3) e1,

Busch-Vishniac, I., West, J., Barnhill, C., Hunter, T., Orellana, D., \& Chivukula, R. (2005). Noise levels in John Hopkins hospital. Journal of the Acoustical Society of America, 118(6), 3629.

Chaudhury, H., Mahmood, A., \& Valente, M. (2004). The use of single patient rooms versus mutiple occupancy rooms in acute care environments CHEResearch.org. 
Couper, R. T., Hendy, K., Lloyd, N., Gray, N., Williams, S., \& Bates, D. J. (1994). Traffic and noise in children's wards. Medical Journal of Australia, 160(6), 338.

Cureton-Lane R.A. \& Fontaine D.K., (1997) Sleep in the pediatric ICU, An empirical investigation. American Journal of Critical Care, 6, 1, 56

Dantzer, R. \& Kelley, K. (1989). Stress and immunity: An integrated view of relationships between the brain and the immune system. Life Sciences, 44, 1995-2008.

Diette G. B., Lechtzin, N, Haponik., Devrotes, A., \& Rubin, H.R. (2003) Distraction therapy with nature sights and sounds reduces pain during flexible bronchoscopy: A complementary approach to routine analgesia. Chest, 123(3), 941,

Eiler Rasmussen, S., Experiencing Architecture. MIT Press, Cambridge, 1997

Falk, S. A., \& Woods, N. F. (1973). Hospital noise: Levels and potential health hazards. New England Journal of Medicine, 289(15), 774.

Roenneberg, T, \& Foster, R G. (1997): »Twilight times: light and the circadian system..« Photochem Photobiol 66.5 549-61.

Freedman, N. S., Gazendam, J., Levan, L., Pack, A. I., \& Schwab, R. J. (2001). Abnormal sleep/wake cycles and the effect of environmental noise on sleep disruption in the intensive care unit. American Journal of Respiratory and Critical Care Medicine, 163(2), 451.

Freedman, N. S., Kotzer, N., \& Schwab, R. J. (1999). Patient perception of sleep quality and etiology of sleep disruption in the intensive care unit. American Journal of Respiratory and Critical Care Medicine, 159(4), 1155-1162.

Glaser, R. \& Kiecolt-Glaser, J. K. (2005). “Stress-induced immune dysfunction: Implications for health." Immunology, 5, 243-251

Glod, C. A., Teicher, M. H., Butler, M., Savino, M., Harper, D., Magnus, E., et al. (1994). Modifying quiet room design enhances calming of children and adolescents. Journal of the American Academy of Child \& Adolescent Psychiatry, 33(4), 558.

Hagerman I., Theorell, T., Ulrich, R. S., Blomkvist, V., Eriksen C.A., \& Rasmanis, G. (2005) Influence of coronary intensive care acoustics on the physiological states and quality of care of patients. International Journal of Cardiology, 98(2), 267

Hammerstrøm, K.; Bjørndal, A., (2007) Arkitektur og design for livskvalitet og helse. En kartlegging av foreliggende forskning, no. 20, Kunnskapssenteret, Norge

Harris D.D., Shepley, M. M., White, R.D., Kolberg, K.J., \& Harrel, J. W. (2006)The impact of single family room design on patients and caregivers: executive summary, Journal of Perinatology, 26, p 38,

Hartig, T., Book, A., Garvill, J., Olsson, T., \& Gärling, T. (1995). Environmental influences on psychological restoration. Scandinavian Journal of Psychology, 37, 378.

Heslet L. \& Dirckinck Homfeldt K., (2007)Sansernes hospital, Arkitektens Forlag; København, Denmark,

Hilton, B. A. (1985 Sep). Noise in acute patient care areas. Research in Nursing $\mathcal{E}$ Health, 8(3), 283.

Holahan, C. J. (1972). Seating patterns and patient behavior in an experimental dayroom. Journal of Abnormal Psychology, 80(2), 115.

Holahan, C. J., \& Saegert, S. (1973). Behavioral and attitudinal effects of large-scale variation in the physical environment of psychiatric wards. Journal of Abnormal Psycholology, 82(3), 454 .

Holm, L. (2003). Madens betydning for patienterne. Mad, mennesker og måltider (pp. 279294). København: Munksgaard Danmark. 
Heath, Y., \& Gifford, R. (2001). Post-occupancy evaluation of therapeutic gardens in a multi-level care facility for the aged. Activities, Adaptation \& Aging, 25(2), 21.

Karro, J., Dent, A. W., \& Farish, S. (2005). Patient perceptions of privacy infringements in an emergency department. Emergency Medicine Australasia: EMA, 17(2), 117.

Kearney, A. R., \& Winterbottom, D. (2005). Nearby nature and long-term care facility residents: Benefits and design recommendations. Journal of Housing for the Elderly, 19(3/4), 7.

Keep, P., James, J., \& Inman, M. (1980). Windows in the intensive therapy unit. Anaesthesia, 35(3), 257.

Kemeny, M. E. (2007). "Understanding the interaction between psychosocial stress and immune-related diseases: A stepwise progression." Brain, Behavior, and Immunity, 21 (8), 1009-1018.

Khansari, D., Murgo, A., \& Faith, R. (1990). Effects of stress on the immune system. Immunology Today, 11, 170-175.

Koivula M., Paunonen-limonen, M., Tarkka, M. T., Tarkka, M., \& Laippala, P. (2002) Social support and its relation to fear and anxiety in patients awaiting coronary artery bypass grafting. Journal of Clinical Nursing, 11(5), 622,

Kulik, J. A., Mahler, H. I. M., \& Moore, P. J. (1996). Social comparison and affiliation under threat: Effects on recovery from major surgery. Journal of Personality and Social Psychology, 71(5), 967.

Lack, L. C., \& Wright, H. R. (2007 May). Chronobiology of sleep in humans. Cellular and Molecular Life Sciences, 64(10), 1205.

Laitinen, P., \& Isola, A. (1996). Promoting participation of informal caregivers in the hospital care of the elderly patient: Informal car-givers' perceptions. Journal of Advanced Nursing, 23(5), 942.

Laumann, K., Gärling, T., \& Stormark, K. M. (2003). Selective attention and heart rate responses to natural and urban environments. Journal of Environmental Psychology, 23(2), 125.

Lawson (2010) Healing architecture, Arts \& Health, 2:2, 95-108

Lawson, B.R., \& Phiri, M. (2003). The architectural healthcare environment and its effects onpatient health outcomes. London: The Stationery Office.

Leather, P., Beale, D. Santos, A., Watts, J., \& Lee, L. (2003) Outcomes of environmental appraisal of different hospital waiting areas, Environment $\mathcal{E}$ Behavior, 35(6), 842,

Lee, D. W. H., Chan, A. C. W., Wong, S. K. H., Fung, T. M. K., Li, A. C. N., Chan, S. K. C., (2004). Can visual distraction decrease the dose of patient-controlled sedation required during colonoscopy? A prospective randomized controlled trial. Endoscopy, 36(3), 197.

Lehner J., Eckerberger, C., Walla, P., putsch, G, \& Deecke L., (2000) Ambient odor of orange in a dental office reduces anxiety and improves mood in female patients. Physiology $\mathcal{E}$ Behavior, 71(1-2), 83,

Lewy, A. J., Bauer, V. K., Cutler, N. L., Sack, R. L., Ahmed, S., Thomas, K. H., et al. (1998). Morning vs evening light treatment of patients with winter depression. Archives of General Psychiatry, 55(10), 890.

Lovell, B. B., Ancoli-Israel, S., \& Gevirtz, R. (1995). Effect of bright light treatment on agitated behavior in institutionalized elderly subjects. Psychiatry Research, 57(1), 7.

Macnaughton J., Collins, P., Coleman, S., Kellett, P., Purves, G., \& Soukas A., (2005) Designing for health: Architecture, art and design at the James Cook university hospital. No. R \& D Project B (01)13) Department of Health, 
Malkin, J., A (2007) Visual Reference to Evidence-Based Design. The Center for Health Design, Concord, California

Marcus C. C. \& Barnes M.,(1995) Gardens in healthcare facilities: Uses, therapeutic benefits, and design recommendations. Martinez, CA: Center for Health Design,

Marcus, C. C., \& Barnes, M. (1999). Healing gardens: Therapeutic benefits and design recommendations. (1st ed.) Wiley.

Meyer, T. J., Eveloff, S. E., Bauer, M. S., Schwartz, W. A., Hill, N. S., \& Millman, R. P. (1994). Adverse environmental conditions in the respiratory and medical ICU settings. Chest, 105(4), 1211.

Mlinek, E. J., \& Pierce, J. (1997). Confidentiality and privacy breaches in a university hospital emergency department. Academy of Emergency Medicine, 4(12), 1142.

Moorthy, K., Munz, Y., Undre, S., \& Darzi, A. (2004). Objective evaluation of the effect of noise on the performance of a complex laparoscopic task. Surgery, 136(1), 25.

Mroczek J., Mikitarian, G., Vieria, E., \& Rotrius, T., (2005 ) Hospital design and staff perceptions. The Health Care Manager, 24(3), 233

NHS Estates. (2005). Ward layouts with single rooms and space for flexibility, NHS Estates.

Olsen, J. C., \& Sabin, B. R. (2003). Emergency department patient perceptions of privacy and confidentiality. Journal of Emergency Medicine, 25(3), 329.

Olsen, R. V. (1984). The effect of the hospital environment: Patient reactions to traditional versus progressive care settings. Journal of Architectural and Planning, 1(2), 121.

O'Neill, M. J. (1991a). Evaluation of a conceptual model of architectural legibility. Environment \& Behavior, 23(3), 259.

O'Neill, M. J. (1991b). Effects of signage and floor-plan configuration on wayfinding accuracy. Environment \& Behavior, 23(5), 553.

Pallasma, J. ( 2005) The eye of the skin, Wiley \& son, West Sussex, England

Parsons et al., The view from the road: Implications for stress recovery and immunization. Journal of Environmental Psychology, 18, 113, 1998

Pattison, H. M., \& Robertson, C. E. (1996). The effect of ward design on the well-being of postoperative patients. Journal of Advanced Nursing, 23(4), 820.

Prodromidis M., Field, T., Arendt, R., Singer, 1., Yando, R., Bendell, D., (1995 ) Mothers touching newborns: A comparison of rooming-in versus minimal contact. Birth, 22(4), 196-201,

Rivkees, S. A., Mayes, L., Jacobs, H., \& Gross, I. (2004). Rest-activity patterns of premature infants are regulated by cycled lighting. Pediatrics, 113(4 part 1), 833.

Rodiek, S. (2005). Resident perceptions of physical environment features that influence outdoor usage at assisted living facilities. Journal of Housing for the Elderly, 19(3/4), 95.

van den Berg, , A.E.,( 2005) Health Impacts of Healing Environments, Foundation 200 years University Hospital Groningen, Nederland

Sallström C., (1987) Relatives' experience of the terminal care of long-term geriatric patients in open-plan rooms. Scandinavian Journal of Caring Sciences, 1(4), 133,

Sanderson, P. M., Tosh, N., Philp, S., Rudie, J., Watson, M. O., \& Russell, W. J. (2005). The effects of ambient music on simulated anaesthesia monitoring. Anaesthesia, 60(11), 1073.

Shepley, M. M. (2002). Predesign and postoccupancy analysis of staff behavior in a neonatal intensive care unit. Children's Health Care, 31(3), 237.

Shertzer, K. E., \& Keck, J. F. (2001). Music and PACU environment. Journal of PeriAnesthesia Nursing,16(2), 90. 
Slevin, M., Farrington, N., Duffy, G., Daly, L., \&Murphy, J. F. (2000) Altering the NICU and measuring infant responses. Acta Paediatrica, 89, 5, 577,

Smidt, S., Holm, L., \& Fleischer, M. K. (1996) The socio-psychological significance of hospital meals: The impact on introduction of a new catering system in a children's cancer ward. Scandinavian Journal of Nutrition, 40 (1)

Sommer, R., \& Ross, H. (1958). Social interaction on a geriatrics ward. International Journal of Social Psychiatry, 4(2), 128.

Sturdavant, M. (1960). Intensive nursing service in circular and rectangular units. Hospitals, JAHA,34(14), 46-71.

Symon, A., Paul, J., Butchart, M., \& Carr, V., (2007) The effects of the interior environment design on service users and staff in maternity facilities No. R\&D Projekt B (02)11)Department of Health,

Tarkka, M. T., Paavilainen, E., Lehti, K., \& Astedt-Kurki, P. (2003). In-hospital social support for families of heart patients. Journal of Clinical Nursing, 12(5), 736.

Terman, J. S., Terman, M., Lo, E., \& Cooper, T. B. (2001). Circadian time of morning light administration and therapeutic response in winter depression. Archives of General Psychiatry, 58(1), 69.

Topf, M., Bookman, M., \& Arand, D. (1996). Effects of critical care unit noise on the subjective quality of sleep. Journal of Advanced Nursing, 24(3), 545.

Tse M.M.Y., (2002) The effect of visual stimuli on pain threshold and tolerance. Journal of Clinical Nursing, 11(4), 462,

Ulrich R. S.,( 1981) Natural versus urban scenes: Some psycho physiological effects. Environment \& Behavior, 13, 523,

Ulrich R.S., (1984) View through a window may influence recovery from surgery. Science, 22, (4647) 420,

Ulrich, R. S., Simons, R. F., \& Miles, M. A. (2003). Effects of environmental simulations and television on blood donor stress. Journal of Architectural \& Planning Research, 20(1), 38.

Ulrich, R.S., Kellert, S. R., Heerwagen, J. H., \& Mador, M. (2008) A review of the research literature on evidence-based healthcare design. HERD, 1(3), 61.

Van den Berg, A. E., Koole, S. L., \& Van der Wulp, N. Y. (2003) Environmental preference and restoration: How are they related? Journal of Environmental Psychology, 23, 135

Van der Berg, A. E. (2005) Health Impacts of Healing Environments, University Hospital Groningen, Netherland

Van Someren, E. J., Kessler, A., Mirmiran, M., \& Swaab, D. F. (1997) Indirect bright light improves circadian rest-activity rhythm disturbances in demented patients, Biological Psychiatry 41(9), 955

Verderber S., (1986) Dimensions of person-window transactions in the hospital environment. Environment \& Behavior, 18(4), 450

Vinzio, S., Ruellan, A., Perrin, A. E., Schlienger, J. L., \& Goichot, B. (2003). Actigraphic assessment of the circadian rest-activity rhythm in elderly patients hospitalized in an acute care unit. Psychiatry and Clinical Neurosciences, 57(1), 53.

Wakamura T. \& Tokura H,( 2001) Influence of bright light during daytime on sleep parameters in hospitalized elderly patients. Journal of Physiological Anthropology and Applied Human Science, 20(6), 345 
Walch J. M., Rabin, B. S., Day, R., Williams, J. N., Choi, K., \& Kang, J. D. (2005 ) The effect of sunlight on post-operative analgesic medication usage: A prospective study of spinal surgery patients. Psychosomatic Medicine, 67, 156

Wallace-Guy, G., Kripke, D., Jean-Louis, G., Langer, R., Elliott, J., \& Tuunainen, A. ( 2002 ) Evening light exposure: Implications for sleep and depression. Journal of the American Geriatrics Society, 50(4), 738

Whitehouse, S., Varni, J. W., Seid, M., Cooper-Marcus, C., Ensberg, M. J., Jacobs, J. R., et al. (2001). Evaluating a children's hospital garden environment: Utilization and consumer satisfaction. Journal of Environmental Psychology, 21(3), 301.

Wilson, L. M. (1972) Intensive care delirium: The effect of outside deprivation in a windowless unit. Archives of Internal Medicine, 130(2), 225.

Wright, P., Hull, A. J., \& Lickorish, A. (1993) Navigating in a hospital outpatients' department: The merits of maps and wallsigns. Journal of Architectural E Planning Research, 10(1), 76.

Yinnon, A. M., Ilan, Y., Tadmor, B., Altarescu, G., \& Hershko, C. (1992) Quality of sleep in the medical department. British Journal of Clinical Practitioners, 46(2), 88.

Zahr, L. K., \& de Traversay, J. (1995). Premature infant responses to noise reduction by earmuffs: Effects on behavioral and physiologic measures. Journal of Perinatology, 15(6), 448.

Zimring, C. (1990). The costs of confusion: Non-monetary and monetary costs of the emory university hospital wayfinding system. Atlanta, GA: Georgia Institute of Technology. 


\section{Abstracts in English}

\section{Aesthetics, health and illness}

\section{Regner Birkelund}

The article highlights the importance for health and illness, which has been ascribed to aesthetics in different historical periods. The starting point is ancient Greece where the belief in the positive impact of aesthetics on health and illness was manifested in the architectural decor and artistic embellishments of the numerous medical sanctuaries. In addition, the article underlines the way in which key philosophers within the phenomenological tradition connected the aesthetic impression to health-based life phenomena such as love of life, courage for life and well-being. A line is drawn from the historical and phenomenological perspective on aesthetics and health to more recent research which confirms the positive impact of aesthetic impressions. 


\title{
The medical "mealspace": Is the architecture overlooked or forgotten here?
}

\author{
Tenna Doktor Olsen Tvedebrink, Anna Marie Fisker \& Poul Henning \\ Kirkegaard
}

Today the term 'hospital' is commonly used about the public space where the patients are examined and treated. However, being cured from sickness is often not only a matter of medical or surgical treatments, but a matter of the entire 'medical space' of care and caring established around the patient for instance with meals and nursing during hospitalization. But it is also, we would like to argue, about the architecture; the house framing the entire space. With this article, and on the background of the project MORE, we would like to study the connection between sickness, meals, and architecture. Methodologically, we take our point of departure in the theory on the elements of architecture developed by the architect Gottfried Semper, who back in the late 19th century formed the basis for the contemporary and modern architectural-theoretical definition of "space" as experienced phenomenon. On the background of Semper's theoretical framework and based on the description of a patient meal from the renaissance hospital Santa Maria Nouva, we provide an example of how the architecture of the "mealspace", through an intentional staging of the meal rituals together with the medical treatments, was an essential part of the 'medical space'. Even though this scenario seems theatrical today, we think, that this historical description could contribute to a greater understanding of the 'medical space' and the design of hospital architecture in the future. With this article we, as such, wish to argue for a stronger focus on the architecture of the "mealspace" in the future hospitals, as well as in research related the 'medical space'.

\section{The spatiality of the meal - an arena for health promotion?}

\author{
Rikke Nygaard, Mia Brandhøj, Camilla Berg Christensen \& Bent Egberg \\ Mikkelsen
}

This article wishes to break with a reductionist approach to the understanding of food and meals seen only as a question of nutrition and contribute, rather, to the 
development of a new and broader analytical framework which is able, to a greater extent, to apprehend the interaction between food, meals and health in order to be able to identify potentially unexploited spaces for health promotion. In this article we focus on some of the 'foodscape studies' which have recently emerged within the scientific literature around the area of food and meals. Foodscapes provides an interesting analytical framework, as it offers an insight into the complex interaction between availability, actors - including those eating, those selling and those serving - and with the physical environment in which our choice of meal is made. In our research in public health nutrition and meal science we are investigating how this analytical framework can be applied to the meals that surround us in our everyday lives outside of the domestic sphere. In this article we look at a number of the most important contributions from the foodscapes literature and offer a model, which aims at operationalizing analyses with a foodscapes approach for the purposes of making this complex approach more manageable in specific analyses. In order to exemplify how this can be done, the possibilities of the model are demonstrated in our work with health promoting spaces, specifically with cases from vocational schools and from the bus driver business.

\section{Entering 'Sacred Space'. On Chaplaincy Care in Danish Hospitals}

\section{Hanne Bess Boelsbjerg}

In Danish hospitals spiritual care is offered by chaplains to all patients, irrespective of whether or not the patient is religious. This article explores the room in which such spiritual care is provided. Presenting insights from interviews with 15 chaplains of Muslim or Christian faith together with an observation of a conversation between a Christian chaplain and a patient, the article seeks to devel-op a contextual understanding of how spiritual care is provided. The article argues that the chaplain uses rituals and metaphors to demarcate the boundaries of an invisible space used for meaning-making. If the chaplain and the patient establish a trustworthy relationship, the use of rituals can create a sense of 'sacred space.' This analytic term is used to help us visualize the invisible room where patients have the opportunity to re-evaluate their beliefs and values. The concept of 'sacred space' draws on the theories of Emile Durkheim, Victor Turner and Gregory Bateson. It relies on the concept of non-communication. Although it cannot be ut- 
tered, some of the understanding of this 'sacred space' can be turned into a flexible metaphor understood in different ways by both chaplain and patient. Through a negotiation between the different understandings of reality the patients may experience a support as they see themselves as more than severely ill bodies.

\section{Illness and self-image across spaces}

\section{Iben Emilie Christensen \& Sofie Ilsvard}

This article deals with the relationship between physical spaces, illness and selfimage amongst people with severe physical disabilities or impairment of function, who have been prescribed gratuitous physiotherapy as part of their treatment. The study has been based on field-work conducted within the framework of a phenomenological-hermeneutical approach, with the pivotal theme pertaining to the subjective and beneficial experiences of the participants, as well as identifying ways for participants to integrate the institutional frame of the clinic of physiotherapy as an integral part of their everyday lives. Despite the fact that participants are typically engaged in lifelong treatments in clinics of physiotherapy, the existing knowledge of their experience hereof, is quite sparse. The aim of the article is therefore to gain insight into the participants lived experiences of training within the environment of the physiotherapeutic clinic - thus to examine the significance of physical space in relation to the self-image of the participants. The empirical analysis is established on a relational perspective, as the participants address both their perception of illness and self-image dependent on their location during treatment, and on their subjective spatial understanding. In this context it is argued that the definition and understanding of physical space in relation to the participants' self-images emerge and become visible through the comparison and interpretation of other various physical spaces. In examining the self-image of patients, the paradoxical conclusion arises that the clinic of physiotherapy, a place where illness is treated and practiced, is not experienced by participants as a 'space of illness', but as a much-needed free space from illness where they feel like 'regular people'. In contrast to this are the private homes and the public space, which are far more likely to represent a 'space of illness', as these are the spaces where impaired function and disability create barriers for the participants' social lives and where the limits between normalcy and deviance are defined. 


\section{Taming pleasure - a spatial analysis of a Danish heroin clinic}

Birgitte Schepelern Johansen E Katrine Schepelern Johansen

Substance abuse treatment with medically prescribed heroin is new in a Danish context. This article addresses the complicated transformation of heroin from illegal street drug to prescribed medicine through an analysis of the spatial arrangements in one of the five new clinics in Denmark. The article shows how the heroin clinic stages this modelling of heroin as medicine through certain spatial arrangements and means of control with the aim of separating the heroin from the street culture it has been part of before and from the pleasure that the users are striving for. The goal of this process is to marginalise the heroin from the life of the users. At the same time the analysis reveals how the heroin embed other possible presences - as social taboo, as illegal drug, as pleasure - and these other presences constantly surfaces in the ideals of the staff and in the behaviour of the clients: in their high and their ways of appropriating space. Thus, the heroin should be understood as a 'messy object' that makes the space for treatment inevitably contradictory.

\section{Environmental qualities and patient well-being in hospital settings}

\section{Anne Kathrine Frandsen}

Within the last decades the impacts of the physical environments of hospitals on healing and health-care outcomes have been subject to ample research. The amount of documentation linking the design of physical environments to patient and staff outcomes is increasing.

A Danish research project undertaken by Architecture and Design and the Danish Building Research Institute (Aalborg University) set out in 2008 to review research on the impact of the environmental qualities of health-care facilities on patients and staff. The objective of the review team was to develop a tool that would allow an overview of this research, needed by construction clients and decision-makers in Denmark responsible for large investments in future hospitals and healthcare environments in the decade to come. 
The present paper offers an overview of the findings of the review team. Its point of departure is the categorisation developed during the study, which facilitated the sorting and communication of the findings. In this categorisation, research findings are grouped according to their focus on specific spatial qualities - such as light and acoustics - and not according to the different diagnoses, which may be linked to such spatial qualities, like stress and depression. In other words, the application of this categorisation foregrounds the importance and the convenience of looking at spatial qualities of the physical environment, when addressing issues related to patient or staff wellbeing.

Indenfor de sidste 20 år har der været en voksende forskningsmæssig interesse for hospitalers fysiske rammer og disses betydning for patienters velvære og helbredelsesforløb, samt personalets velbefindende. Tilsvarende er antallet af forskningsresultater, der knytter udformningen af de fysiske rammer på hospitaler sammen med patienters og personalets velbefindende, stigende.

I 2008-09 gennemførte Arkitektur og Design og Statens Byggeforskningsinstitut ved Aalborg Universitet et litteraturstudium af den forskning, der undersøger om og hvordan kvaliteter ved de fysiske rammer påvirker patienter og personale. Målet med litteraturstudiet var at udvikle et værktøj, der kunne give bygherrer og beslutningstagere med ansvar for byggeriet af de mange nye hospitaler i Danmark, et overblik over forskningen på feltet.

Denne artikel søger at give et overblik over litteraturstudiets resultater. Dette gøres med udgangspunkt i en kategoriseringsmodel, udviklet som en del af studiet med henblik på at sortere og kommunikere de iagttagne forskningsresultater. I modellen kategoriseres forskningsresultaterne ud fra, hvilke faktorer i de fysiske rammer, de beskriver - f.eks. lys og akustik - og ikke ud fra de diagnoser, som disse faktorer kan sættes i forbindelse med - f.eks. stress og depression. Ved at kategorisere den iagttagne forskning med udgangspunkt i denne model, fremhæves de kvaliteter ved hospitalernes fysiske rammer, som synes at spille en rolle for patienters og personalets velbefindende. 


\section{Forfatterliste}

\section{Regner Birkelund}

Cand.cur., ph.d. og dr.phil. Lektor ved Institut for Folkesundhed, Aarhus Universitet. Har publiceret en lang række bøger og artikler, der bl.a. har æstetikkens betydning for sundhed, velvære og erkendelse som omdrejningspunkt. Senest har han udgivet antologien Ved livets afslutning, i hvilken æstetikkens betydning i forbindelse med palliativ omsorg, pleje og behandling belyses.

\section{Tenna Doktor Olsen Tvedebrink}

Phd-studerende i «Hospital Mealscape Design» ved Institut for Byggeri \& Anlæg, Aalborg Universitet. Uddannet civilingeniør med speciale i Arkitektur, fra Institut for Arkitektur \& Design ved Aalborg Universitet, og er enkeltfagsstuderende fra Københavns Universitet, Institut for Fødevareforskning og Institut for Humanernæring. Forskningsområder er arkitektur, design, interiør, spisemiljøer, måltider og madhistorie.

\section{Anna Marie Fisker}

Lektor ved Aalborg Universitet, sektionsleder af sektionen Food+Design, Institut for Byggeri og Anlæg, Aalborg Universitet. Uddannet arkitekt maa fra Århus Arkitektskole og er PhD i «Mad og Arkitektur» fra Aalborg Universitet, Institut for Arkitektur, Design og Medie Teknologi. Forskningsområder er arkitektur, design, interiør, madkultur, gastronomi, måltider og madhistorie.

\section{Poul Henning Kirkegaard}

Professor ved Aalborg Universitet, Institut for Byggeri \& Anlæg. Uddannet civilingeniør med speciale i bygningskonstruktion og er PhD i «Optimal Design of Measurement Programs for the Parameter Identification of Dynamic Systems». Forskningsområder er 
blandt andet rumakustik, arkitektonisk kvalitet, digital arkitektur, bærende konstruktioner, bygningsmaterialer og integreret design.

\section{Rikke Nygaard}

Rikke Nygaard forfølger i denne artikel en tidligere interesse i hverdagslivsperspektiver på sundhed og sundhedsfremme og hverdagslivet som arena for læring. Og hvor hun tidligere har arbejdet med forældreskabet, seksualitet og køn forfølger hun i denne artikel via et Foodscapes perspektiv maden, måltidet og arbejdslivet som specielt egnede arenaer for sundhedsfremme.

\section{Mia Brandhøj}

Mia Brandhøj har etableret både forsknings- og praksis- erfaring med at implementere sundhedsfremmende indsatser på små- og mellemstore danske arbejdspladser, gennem tværvidenskabelig tilgange i forskningsprojekter og som konsulent i branchen. Mias særlige interesse i Foodscapes studierne og litteraturen er blevet udbygget i litteraturgennemgang, Ph.d. kursus, rapport og nu i denne artikel.

\section{Camilla Berg Christensen}

Camilla Berg Christensen har primært arbejdet med kost- og motions-vaner blandt unge. Camilla har en speciel interesse i sundhedsfremmende indsatser på ungdomsuddannelser i et interventionsorienteret perspektiv. I denne artikel udforskes Foodscapes tilgangen i forhold til hvordan et sådan perspektiv kan berige arbejdet med sundhedsfremmende indsatser på ungdomsuddannelserne.

\section{Bent Egberg Mikkelsen}

Professor, Ph.D, Forskningskoordinator, Kandidat i levnedsmiddelvidenskab (cand. brom.), 1984, PhD i Sociologi, RUC, TekSam. Forsker i ernæring og bæredygtigt forbrug i udespisningen, særligt skoler, børnehaver, arbejdspladser og sygehuse. Har særlig fokus på participatorisk udvikling af interventioner samt på måling af effekter af interventioner og strategier. Indtager og har indtaget en række ekspertfunktioner for en række internationale organisationer i spørgsmål om folkesundhedsernæring og settings, herunder Europarådet, WHO og EU kommisionen. Co editor på tidsskriftet Public Health Nutrition.

\section{Hanne Bess Boelsbjerg}

Hanne Bess Boelsbjerg (1973) er cand.mag. i religionsvidenskab (AU). Fra 2006 tilknyttet Center for Forskning i Eksistens og Samfund, Sociologisk Institut, Københavns Universitet. Siden 2010 ph.d.-stipendiat ved forskningsenheden 'Helbred, Menneske og Samfund' på Institut for Sundhedstjenesteforskning på Syddansk Universitet. Hendes ph.d.-projekt omhandler kristne og muslimske kræftpatienter i palliative forløb. 


\section{Iben Emilie Christiensen}

Iben Emilie Christensen er uddannet cand.scient.soc. fra Institut for Sociologi, Socialt Arbejde og Organisation, Aalborg Universitet, i 2011. Iben er projektleder i KORA, Det Nationale Institut for Kommuners og Regioners Analyse og Forskning (tidligere Dansk Sundhedsinstitut), hvor hun ved hjælp af kvalitative metoder inddrager og kombinerer borgeres og fagpersoners erfaringer med $f x$ forebyggelsesindsatser og behandling $i$ sundhedsvæsenet.

\section{Sofie Ilsvard}

Sofie Ilsvard er uddannet cand.scient. soc. fra Institut for Sociologi, Socialt arbejde og Organisation, Aalborg Universitet, i 2011. Sofie er ansat som videnskabelig assistent ved Sektion for Almen Medicin, Institut for Folkesundhed, Aarhus Universitet, og forsker i deltagelse og rekruttering ved forebyggelsesindsatser.

\section{Birgitte Schepelern Johansen}

Birgitte Schepelern Johansen er ph.d., adjunkt ved Minoritetsstudier, Institut for Tværkulturelle og Regionale Studier, Københavns Universitet. Hun er religionssociolog af uddannelse, men har gennem en årrække primært arbejdet med forholdet mellem normalitet og afvigelse i et videnssociologisk perspektiv.

Katrine Schepelern Johansen Katrine Schepelern Johansen er ph.d. i antropologi og ansat som projektleder ved KORA (Det Nationale Institut for Kommuner og Regioners Analyse og Forskning). Hendes pri- mære forskningsinteresse er psykiatri og stofmisbrugsbehandling og hun har senest arbejdet med en evaluering af det danske tilbud om lægeordineret heroin.

\section{Anne Kathrine Frandsen}

Anne Kathrine Frandsen er arkitekt og Ph.d. fra Kunstakademiets Arkitektskole. I dag er hun ansat på Statens Byggeforskningsinstitut, Aalborg Universitet, hvor hun dels forsker i byggeprocesser og implementering af ny viden og teknologi i design- og byggeprocesser, dels i oplevet kvalitet i arkitektur. 